\title{
The Peculiarities of the Use of Electronic Course Books in the Process of Specialists' Training at the University
}

\author{
Gulshara Begarisheva \\ Department of Computer Science and Computer Engineering at Caspian State University of Technologies and \\ Engineering Named after S. Yesenov, Aktau City, The Republic of Kazakhstan \\ Email: ggb021@mail.ru
}

Received 16 May 2014; revised 29 June 2014; accepted 14 July 2014

Copyright @ 2014 by author and Scientific Research Publishing Inc.

This work is licensed under the Creative Commons Attribution International License (CC BY). http://creativecommons.org/licenses/by/4.0/

c) (i) Open Access

\section{Abstract}

The paper considers the problems and conditions of the use of electronic course books at the university. The models of two different multimedia course books are presented in the paper. The peculiarities of their design and use are discussed. On the basis of the analysis of foreign and local references and own experience the author presents possibilities of the use of new information technologies in the teaching process of the university. The specificity of electronic educational tools are characterized, the essence of the approaches for electronic course books design is discovered, and peculiarities of the use of electronic course books in the conditions of the university specialists' training are discussed.

\section{Keywords}

New Information Technologies, Use of New Information Technologies Whilst Specialists' Training, Use of Electronic Course Books, Multimedia Course Books Design

\section{Introduction}

At present in the conditions of continuous change of the level of life, globalization of social development and integration of the Republic of Kazakhstan and other CIS countries into world community new requirements to specialists' training, first of all in the area of strengthening personality's intellectual abilities, intensification of the processes of individual's intellectual development have appeared.

First of all it is the use of possibilities of modern information technologies tools that allow initiating processes of the development of definite types of thinking, intensify the processes of memory development, attention, ob- 
servation, leadership qualities development, capabilities of organization activity, development of creative abilities stimulation.

\section{Information Technologies in the Educational Process of the University}

The world "technology" is of Greek origin, meaning "knowledge about the mastery". The term "teaching technology" was used in the USA in the 50-s of the XX century to name the results of the search of the ways of designing efficient education process. Investigating the evolution of the phenomenon "pedagogic technology", V.I. Bogolyubov, M. V. Klarin, F. Yanushkevich on the basis of the analysis of foreign and local sources show the development of the idea of "technologies in education" (implementation of the first programs of audio-visual teaching and further inculcation of engineering thought achievements in the process of teaching), through "the technology of education" (scientific description of means and methods of pedagogical process, leading to the result that was planned) [1]-[3].

Nowadays the researches pay special attention to new information technologies and their tools. New information technologies tools are soft hardware, functioning on the basis of microprocessor computer engineering and also modern tools and systems of information exchange, providing operations on information collection, producing, storage, accumulation, processing and transmission.

Realization of the new information technologies possibilities mentioned above allows to organize such types of activities as information collection, storage and processing; interactive dialogue (of the user with the program; student with a teacher); automated control (self-control) of the results of education activity, correction of the control results, training, testing.

Information technologies include programmed education, intellectual teaching, expert systems, hypertext and multimedia, microcosms, teaching imitation, demonstration. These methods should be used depending on educational aims and education situations, when in some cases it is necessary to understand the students' needs and in others-knowledge analysis in the course area is necessary and in the third ones-psychological principle of education plays the main role.

The most important characteristic of new information technologies nowadays are:

1) Types of computer training systems (training machines, education and training, program training, intellectual tutoring);

2) Teaching tools (LOGO, teaching via open microcosms, hypertext, multimedia);

3) Instrumental systems (programming, text processors, databases, presentation instruments, author systems, group teaching instruments).

The most important in new information technologies is a computer with corresponding technical support and software. Thus, a new information technology is a process of information preparation and transmission to the student with the help of computer. New information technologies raise the level of the education at the university at a new qualitative level, modernizing education process, changing the form and contents of pedagogical activity.

One of the most common applications of new information technologies in the teaching process of the university is an electronic course book. Traditionally all electronic course books are based on module principle.

The term "module" (from Latin-“measure") came to pedagogy from computer science where it denotes the construction applied to different information structures, providing their flexibility and reconfiguration.

Module is a relatively independent unit of some system having definite functional load. It is a definite part of information and action, enough to form some knowledge or skills.

In pedagogy the notion "module" is used to denote some basic unit of education contents taking into account attributive characteristics. Most researchers' opinion is that module is a part of education contents, its simple autonomous, independent, standardized, conceptual unit. At the same time module is not a closed, locked unit. If it is necessary new units can be added to it. Every module is self-determined: it determines the area of activity, methods and forms of work.

One of the means of new information technologies widely used nowadays in the system of higher education is electronic multimedia course book.

There is an established stereotype that an electronic course book is just a copy of paper course book, is not a scientific one and cannot serve the basis to design electronic course book. Objectively there is a number of essential differences of an electronic course book from a polygraphic one that makes it impossible to create it us- 
ing the analogue of the traditional one.

Essential differences of an electronic course book from the traditional one are:

1) Specific system of education process management, placed in the course book content, including the means of education material nonlinear structuring and optimization, the means of knowledge diagnosis and correction, feedback subdivided network, etc.;

2) Methodical and psychological methods allowing making the process of education material acquisition faster;

3) Graphic means providing high level of visualization;

4) Multimedia means, allowing organizing laboratory practical classes with higher results and other similar work.

References analysis has shown that while designing computer courses different approaches are used, requiring taking into account perspective didactic and psychological concepts, contents and logic, course specificity, methods of its teaching. Thus, B.S. Gershunskiy offers to take into account general stages of the complete cycle of computerized learning while computer courses design: definition of objectives, education material acquisition process, practical application, education results control and self-control, teaching activity and learning activity correction [4]. The author underlines the idea, that while composing teaching programs it is necessary to predict the possibilities to adapt the level of difficulty of the presented information, statement tempo, the measure of students' independence, take into account their individual peculiarities.

Skibitskiy E.G. and Holdina L. I. underline the fact that computerized courses are cybernetic systems [5]. Thus during the process of the projecting it is reasonable to follow a number of general systematic principles (purposefulness, organization, dynamics, integrity, evolution, adaptiveness, poly functionality, etc.). The most important component of the process is course structure determination which is considered from different points of view: the contents of education information presented to the student, goals of education and up-bringing, age and psychological peculiarities of teachers and students; the level of teachers' readiness; education process differentiation and individualization, regional peculiarities of educational institutions functioning; type of computer equipment, etc.

G. K. Nurgaliyevahas developed and is widely implementing pedagogic technology of electronic textbooks design for school and universities on different disciplines based on module principles in the Republic of Kazakhstan [6].

O. Tyshenko considers that while developing computerized teaching systems it is necessary to solve a complex of various problems, including education-methodical, psychological, organization, technical, economic aspects and all these components should be closely connected with each other [7].

According to Y. Y. Usachev's opinion, the main objective is to create the approach to develop intellectual electronic textbook for the specific course, allowing completing the following functions:

1) Determine the level of student's knowledge;

2) Synthesize study plan;

3) Teach by way of presenting the material according to the study plan [8].

Different approaches are realized in practice in modern conditions while projecting and designing electronic courses. At the same time there is no unique system of didactic requirements for electronic course books.

Thus the objective of the research was to develop and substantiate a number of didactic requirements for electronic course books applied in the education process.

As in this case we speak about teaching, that supposes active interaction of the student with the teacher, the presence of the teacher in the system with the use of electronic means is obligatory, as first of all the function of education process management belongs to him. Computer technologies make it possible to automatize the function of education process management. The leading methods of managing the process of education in distant learning were singled out by O.P. Okolelov. They are motivation, structuring and optimization of the course contents; material statement, student's cognitive activity organization, testing the level of the whole course acquisition, correction of the process of theoretic knowledge acquisition, correction of the process of practical skills and abilities acquisition, formation of the requirements to the student on the course [9].

As practice has shown electronic course book, firstly, being an effective tool for teaching can be used in university education process to solve different didactic objectives. Secondly, electronic course book can be used in different forms of training-distant, traditional (full time and part-time), project activity, etc.

The present paper discusses the process of designing two course books for university: one on the History of foreign pedagogy and the second an English multilevel multimedia course book for economists. 
Electronic course book on the history of foreign pedagogy design was preceded by experience analysis (both positive and negative) of traditional university course books design. Eight course books by seven authors were analyzed.

The peculiarity of our approach to electronic course books design is in determining its structural elements and contents characteristics of the subject area, levels of the offered material taking into account professional and research area of the student (bachelor-specialist-master) with more complicated set of knowledge, skills and abilities. Course material choice for the electronic course book was done according to the Regulations of specialists' multilevel training and course program "The History of Pedagogy" for the corresponding stage of education.

Electronic course book "The History of Foreign pedagogy" introduces students with famous teachers of the past, their biography, pedagogical opinions, leading ideas and concepts. The course book presents different tables and schemes, allowing approaching course contents acquisition on the basis of its comparison, systematization and generalization. Tables from general and pedagogical mass media, documents on up-bringing and education issues are presented, fragments from fictions, portraits, photos, pictures, tasks types, tests, creative and research works, crosswords tasks, etc.

The structure of electronic textbook contains the following modules and elements:

1) Modules aggregation as principal structural elements of an electronic course book, having conceptual and contents completeness and filled with multilevel contents (bachelor-specialist-master);

2) General text of electronic course book is presented in the form of hypertext with a number of hyperlinks that allow filling teaching material with different degree of detalization;

3) Module "electronic reader", containing research papers and pedagogic press and also abstracts from pedagogic fiction;

4) Reference module, including contents, assistance on the course, keywords, rubricating and introduction word of the authors of the course book;

5) Illustration module, containing portraits, photos and drawings, symbolic illustrations, schemes;

6) Assessment module, self-assessment and correction, including both automatized tests and tasks to be managed by the teacher (control papers, creative and education research tasks, etc.), crossword tasks, tables, etc.;

7) Module of Internet connection, containing Internet sites of pedagogical themes, to which the students can refer during the work with the course book materials.

Designed model of multilevel electronic course book on the history of foreign pedagogy is presented in Figure 1. As it is seen from the figure, electronic course book in comparison with traditional is enriched with new elements which is possible only using new information technologies that allow to combine the processes of learning, reinforcements and teaching material acquisition control, create conditions for individual style of activity.



Figure 1. Model of electronic course book on the history of foreign pedagogy. 
Also we have designed and implemented in the education process of the university electronic multilevel English course book for economic students.

The peculiarity of our approach to model design of electronic course book was in course specificity taking into account (English language); diagnosing students' English language level proficiency (A, B or C level); designing the course book contents taking into account professional vocabulary of future economists (Figure 2). Principles realized in the requirements and stages of development are reflected in brackets next to the requirement or stage and noted with the number of the principle.

While designing electronic course book we distinguish the following principles, on the basis of which course material should be selected:

1) Based on science;

2) Module structure;

3) Taking into account students' individual peculiarities;

4) Multilevel structure;

5) Learning communicative directivity;

6) Availability;

7) Hypertext and links use;

8) Taking into accounts all skills;

9) Directivity for individual work development;

10) Professional directivity of studied vocabulary.

Every principle, as it is shown in the figure with model, is realized through a group of requirements, that should be taken into account while design.

Requirements to course material organization:

1) Material selection, its organization and structuring.

2) Teaching material development taking into account hypertext technologies, multimedia means.

3) Links instrument design.

Principles
1.based on science;
2.module structure;
3.taking into account students' individual
peculiarities;
4.multilevel structure;
5.learning communicative directivity;
6.availability;
7.hypertext and links use;
8.taking into accounts all skills;
9.directivity for individual work develop-
ment;
10.professional directivity of studied voca-
bulary.

\section{Stages of design}

1.Students' English language proficiency diagnosis. (Principles 3, 5, 8)

2.Analysis of course traditional contents, material selection taking into account different levels of students' English language proficiency, module structure, individualization, taking into account all skills.(Principles 2, 6, 8)

3.Course book approbation and implementation.(Principles 2, 10)

4.Electronic course book contents correc-

tion.(Principles 2, 4, 6, 9)

5.Recommendations of the design of electronic multilevel English course books.(Principles 1, 10)

Requirements
Requirements to course material organization:
1.Material selection, its organization and structuring. (Principle 1)
2.Teaching material development taking into account hypertext
technologies, multimedia means. (Principle 7)
3.Links instrument design. (Principle 7)
Requirements to course component:
1.Correspondence to modern condition of scientific knowledge of
the course. (Principles 1, 8, 10)
2.Correspondence to goals and objectives, solved during the
process of teaching with the help of electronic course book. (Prin-
ciples 4, 5, 8) Requirements to assignments design:
3.Sufficient and relevant information amount. (Principles 6, 8)
4.Taking into account students' initial level. (Principles 3, 4)
1.Diagnostic character of the tasks to determine the degree of for-
mation with the students definite knowledge, skills and abili-
ties.(Principles 3, 4)
2.Clear tasks statement. (Principle 6)
3.Building links between multilevel tasks contents.(Principles 2,
10)
4.Development of students' intellectual skills.(Principles 1, 3, 10)
1.Progress and final tests design.(Principle 4)
2.Tasks for self-assessment design with keys.(Principle 9)
3.Correct statement of tests tasks keys.(Principle 6)
to

Figure 2. Model of designing electronic multilevel English course book for economic students. 
Requirements to course component:

1) Correspondence to modern condition of scientific knowledge of the course.

2) Correspondence to goals and objectives, solved during the process of teaching with the help of electronic course book.

3) Sufficient and relevant information amount.

4) Taking into account students' initial level.

Requirements to assignments design:

1) Diagnostic character of the tasks to determine the degree of formation with the students definite knowledge, skills and abilities.

2) Clear tasks statement.

3) Building links between multilevel tasks contents.

4) Development of students' intellectual skills.

Requirements to assessment:

1) Progress and final tests design.

2) Tasks for self-assessment design with keys.

3) Correct statement of tests tasks keys.

The group of requirements, presented in the model of designing an electronic multilevel English course book for economic students are not universal due to English language course specificity and can be supplemented with other groups of requirements according to the course specificity.

The third structural unit of the model are stages of electronic course books design, including:

1) Students' English language proficiency diagnosis.

2) Analysis of course traditional contents, material selection taking into account different levels of students' English language proficiency, module structure, individualization, taking into account all skills.

3) Course book approbation and implementation.

4) Electronic course book contents correction.

5) Recommendations of the design of electronic multilevel English course books.

Thus, two models of electronic course books on the history of pedagogy and English course book for economic students presented in the paper show the ways of electronic course books design process and ways of use in the education process of the university.

\section{References}

[1] Bogolyubov, V.I. (1991) Pedagogical Technology: Notion Evolution. Soviet Pedagogy, 9, 123-128.

[2] Klarin, M.V. (1995) Pedagogical Technology. Knowledge, Moscow, 3-41.

[3] Yanushkevich, F. (1986) Teaching Technology in the System of Higher Education. Moscow, 20.

[4] Gershunskiy, B.S. (1998) Philosophy of Education for the XXI Century (In Search of Practically Oriented Concepts). Moscow Psychological-Social Institute, Moscow, 607.

[5] Skibitskiy, E.G. and Hrapchenkov, V.G. (2008) Pedagogy of High School. Novosibirsk, 260.

[6] Nurgaliyeva, G.K. (1998) Pedagogy of Professional Education. Almaty, 12-13.

[7] Tyshenko, O. (2000) The Dialogue of Computer and Student. Higher education in Russia, 6, 120-123.

[8] Usachev, Y.E. (2000) Intellectual Course Book Design. Distant learning, 4, 24-28.

[9] Okolelov, O.P. (1999) Systematic Approach to Electronic Course Design for Distant Learning. Pedagogy, 6, 50-56. 
Scientific Research Publishing (SCIRP) is one of the largest Open Access journal publishers. It is currently publishing more than 200 open access, online, peer-reviewed journals covering a wide range of academic disciplines. SCIRP serves the worldwide academic communities and contributes to the progress and application of science with its publication.

Other selected journals from SCIRP are listed as below. Submit your manuscript to us via either submit@scirp.org or Online Submission Portal.
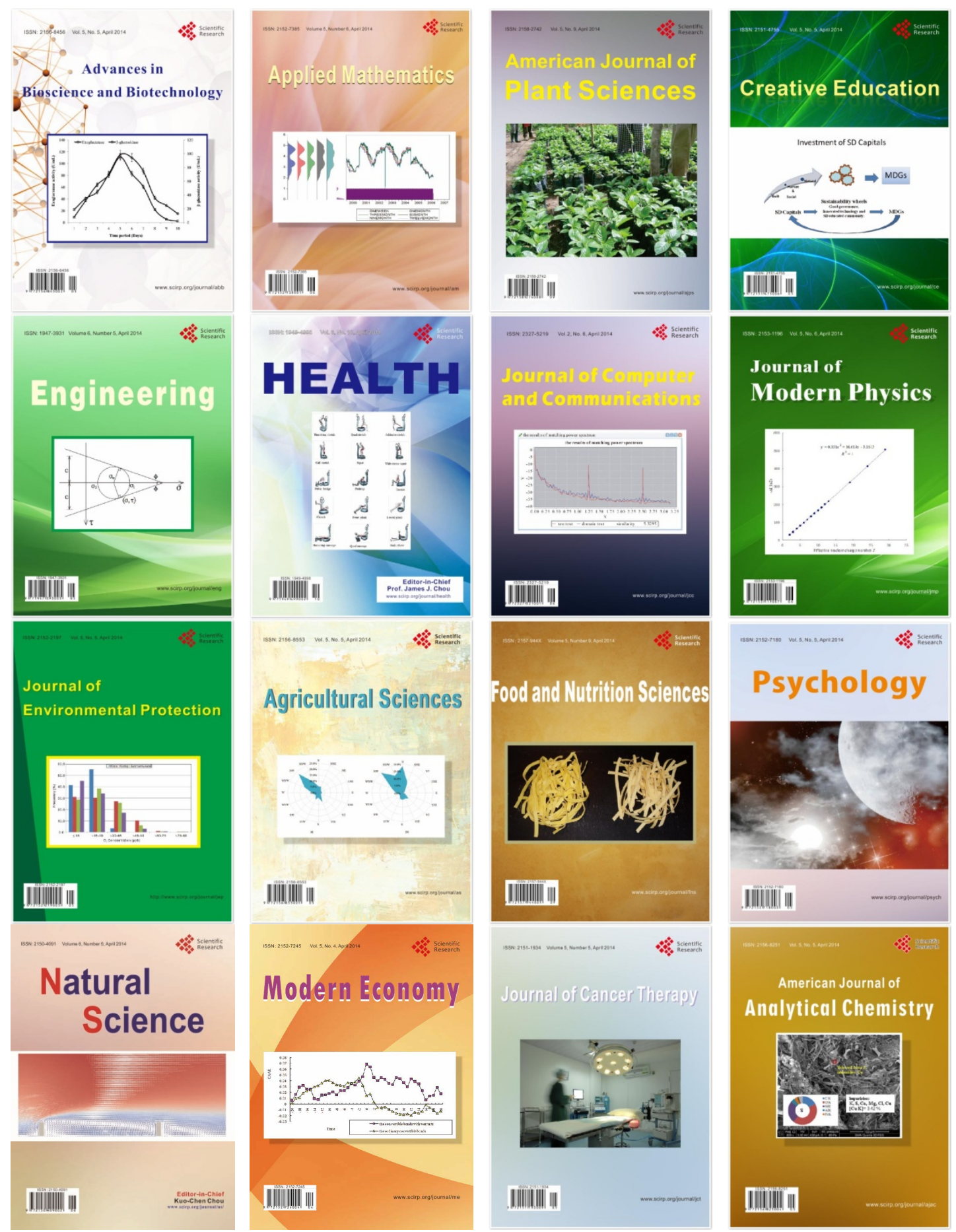